\title{
Compaction and Physical Attributes of the Soil After the Development of Cover Plants
}

\author{
Romário Pimenta Gomes ${ }^{1}$, Anderson Cristian Bergamin ${ }^{2}$, Laércio Santos Silva ${ }^{1}$, Milton César Costa Campos ${ }^{3}$, \\ Vinicius Augusto Filla ${ }^{1}$, Maílson Ferreira Nascimento ${ }^{4}$, Edicarlos Damacena de Souza ${ }^{5}$, José Mauricio da Cunha ${ }^{3}$, \\ Reginaldo de Oliveira ${ }^{1} \&$ Ivanildo Amorim de Oliveira ${ }^{1}$ \\ ${ }^{1}$ University of São Paulo State, Jaboticabal, SP, Brazil \\ ${ }^{2}$ Federal University of Rondônia, Rolim de Moura, RO, Brazil \\ ${ }^{3}$ Institute of Education, Agriculture and Environment, Federal University of Amazonas, Humaitá, AM, Brazil \\ ${ }^{4}$ Federal University of Acre, Rio Branco, AC, Brazil \\ ${ }^{5}$ Federal University of Rondonópolis, MT, Brazil \\ Correspondence: Milton César Costa Campos, Institute of Education, Agriculture and Environment, Federal \\ University of Amazonas, Humaitá, AM, 69800-000, Brazil. Tel: (55)-978114-4618. E-mail: \\ mcesarsolos@gmail.com
}

Received: February 18, $2018 \quad$ Accepted: May 3, $2018 \quad$ Online Published: June 15, 2018

doi:10.5539/jas.v10n7p206 URL: https://doi.org/10.5539/jas.v10n7p206

\begin{abstract}
Compaction problems in heavily tilled soils have been commonly mitigated with the use of cover plants. Aiming to evaluate the effects of compaction on the physical properties of a plyntic Haplic-Alitic Cambisol soil after development of different cover crops, a complete randomized blocks design experiment, with $3 \times 3$ factorial arrangement and four replications, was conducted. Treatments consisted of cultivation of two legume species, crotalaria (Crotalaria juncea L.) and stylosanthes cv. Campo Grande (Estilosantes capitata + Estilosantes macrocephala) and a grass species, brachiaria (Urochloa brizhantha cv. Marandu), subjected to soil compaction: $\mathrm{CM}-$ Conventional soil management (tillage) without additional compaction; $\mathrm{CMc} 4$ and $\mathrm{CMc} 8-$-conventional soil management with additional compaction using a $6 \mathrm{Mg}$ tractor in four and eight wheel passes. Conventional management with additional compaction does not affect significantly the physical attributes at a soil depth of 0.10-0.20 m, and only the soil moisture does not differ according to the soil management, irrespective of the depth and kind of cover plant. Traffic levels in four passes result in an increased soil bulk density and macroporosity in the $0.0-0.05 \mathrm{~m}$, and in soil resistance to penetration and total porosity in the layer up to $0.10 \mathrm{~m}$. Cover crops are important in maintaining soil physical quality to reduce the negative effects of compacting forces, especially to stylosanthes cv. Campo Grande that provided greater soil protection in systems with or without addition of compaction, conditioning the lowest values of bulk density and soil resistance to penetration.
\end{abstract}

Keywords: mechanization, mechanical resistance to penetration, aerial plant mass, multivariate

\section{Introduction}

Characterization of the effects of management systems on soil degradation and physical quality is very important (Servadio, Marsili, Vignozzi, Pellegrini, \& Pagliai, 2005; Martinkoski, Vogel, Jadoski, \& Watzlawick, 2017) and can be assessed through the soil bulk density, macro and microporosity, aggregates stability, mechanical penetration resistance and water infiltration in soil (Vasconcelos, Souza, Cantalice, \& Silva, 2014; Gomes et al., 2017). Most of the studies on Amazon degradation deal only with the removal of forest cover (deforestation), not computing alterations caused by farming, especially when we observe the physiognomy areas of natural fields (steppe savanna) that are largely present in southern Amazon.

Understanding and quantifying the impact of land use and management on the soil physical quality are vital for the development of sustainable cropping systems (Marsili, Servadio, Pagliai, \& Vignozzi, 1998). G. Souza, M. Souza, Silva, Barbosa, and Araújo (2014) observed that compacted soils exhibit a decreased volume of macropores and water infiltration and an increased soil density and penetration resistance. Tillage, or mechanical soil management, causes changes in the pores shape, reduction of channel dimensions and, consequently, in soil water permeability (Castro, Vieira, Siqueira, \& Andrade, 2009). 
Studies such as those by Rosa and Lima (2017), conducted with different cover plants, have demonstrated the beneficial effects of different types of cover plants and their residues left on soil. These effects occur in the soil chemical and physical properties and in yields of crops that will be cultivated afterwards. This is because cover plants change soil aggregation by the mechanical action of roots or the excretion of substances with cementing action and, indirectly, providing nutrients to the soil fauna (Souza Neto, Andrioli, Beutler, \& Centurion, 2008). Teodoro, Oliveira, Silva, Fávero, and Quaresma (2011) consider it crucial to study the response of legume crops to edaphoclimatic conditions in regions that lack information, in order to choose the cover plant to be used, thus increasing the chances of success when implemented.

According to Valadão et al. (2015), grasses seem to have their characteristics more severely affected when subjected to compaction. However, Salton et al. (2008) mention that these plants, because of their fasciculate root system, tend to be efficient in improving and maintaining the soil structure compared to plant species that have a taproot system, even in tilled annual crops where the root system is constantly renewed. Thus, more observations in different regional conditions are necessary in order to have more thorough and solid responses for a better decision-making regarding its application.

Changes in the soil physical properties due to tillage and continuous wheel traffic of heavy machinery in soils with a high degree of moisture are frequent (Freddi, Centurion, Beutler, Aratani, \& Leonel, 2007; Bergamin, Vitorino, Franchini, A. Souza, \& R. Souza, 2010). However, processes involving the management of cover plants subjected to environmental variations, particularly soil compaction, should be more discussed, mainly their effects and relationships with the soil physical properties, seeking for an understanding of the soil-plant dynamics in structurally-altered lands. Given this, the aim of this study is to assess the effect of different levels of tractor-induced compaction on the physical attributes of a plyntic Haplic-Alitic Cambisol after cultivation of different cover crops.

\section{Material and Methods}

The study was conducted in the experimental farm of the Federal University of Amazonas, in the municipality of Humaitá, AM ( $7^{\circ} 30^{\prime} 24^{\prime \prime} \mathrm{S}$ and $\left.63^{\circ} 04^{\prime} 56^{\prime \prime} \mathrm{W}\right)$, during the 2011/2012 crop year. The climate in the region, according to Köppen's classification, is rainy tropical, with a dry period of short duration (Am) with relative air humidity between 85 and $90 \%$. Data on the temperature and rainfall during the experimental period are shown on Figure 1 . The experiment was installed in a plyntic Happlic-Alitic Cambisol (Campos, 2009), a loam clay silty soil, with $320 \mathrm{~g} \mathrm{~kg}^{-1}$ of clay, $600 \mathrm{~g} \mathrm{~kg}^{-1}$ of silt and $80 \mathrm{~g} \mathrm{~kg}^{-1}$ of sand, obtained by the pipette method (Empresa Brasileira de Pesquisa Agropecuária [EMBRAPA], 2011).

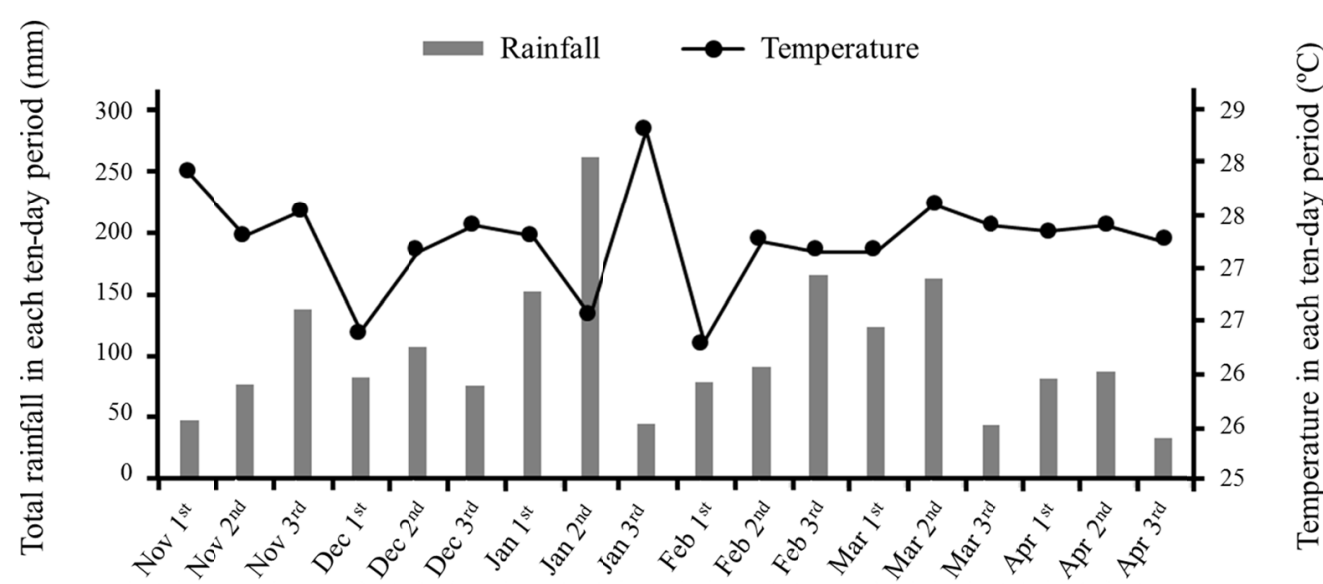

Figure 1. Total rainfall and mean air temperature at each ten-day period of the experimental area from November 2011 to April 2012

The experimental design consisted of randomized blocks with four replications, and three compaction stages: $\mathrm{CM}$-Conventional soil management (tillage) without additional compaction; $\mathrm{CMc} 4$ and $\mathrm{CMc} 8-$ conventional soil management with additional compaction by wheel traffic of a $6 \mathrm{Mg}$ tractor in four and eight passes, respectively. A traffic-induced soil compaction was carried out in November 2011, two days after a period of heavy rain, when the soil water content was $0.28 \mathrm{~kg} \mathrm{~kg}^{-1}$ in the $0.0-0.20$ m layer. A BX 6150 agricultural tractor $(104.4 \mathrm{~kW})$, 
with diagonal tires and $6 \mathrm{Mg}$ of total mass, with inflation pressure of $124 \mathrm{kPa}$ in the front tires (14.9-28 R1) and $137 \mathrm{kPa}$ in the rear tires (23.1-30 R1) was used. Compaction was achieved by tractor wheeling on the entire surface of the plot so that the tires compressed parallel areas between each other. The number of passes varied according to the treatment, and the tractor passed over the former pass so that the entire surface of each plot was wheeled in same number of times.

Sowing of the cover crops was made on February 2, 2012, comprised of: crotalaria (Crotalaria juncea, L.), stylosanthes cv. Campo Grande (Stylosanthes capitata and S. macrocephala) and brachiaria (Urochloa brizantha). Legume plants and grasses were cultivated in plots measuring $5 \mathrm{~m}$ long and $4 \mathrm{~m}$ wide, in a total area of $20 \mathrm{~m}^{2}$, and were sowed with the aid of a sowing machine with the recommended density for each species $\left(\right.$ crotalaria $=30 \mathrm{~kg} \mathrm{ha}^{-1}$, stylosanthes Campo Grande $=3.0 \mathrm{~kg} \mathrm{ha}^{-1}$, and brachiaria $=6.0 \mathrm{~kg} \mathrm{ha}^{-1}$ ), with spacing of $0.33 \mathrm{~m}$ between lines. The sowing machine drill was removed to prevent possible adverse impacts of compaction, using only the cutting disc of the seeds metering device. The cultures were kept free from competition by applying herbicides and did not receive mineral fertilizer.

To assess emergence, the normal seedlings that emerged were counted every day until all replications were stabilized, which in this case was 17 days after emergence. Height of the cover plants was measured during the flowering period from the ground to the plant top, and was carried out in a representatively and randomly in the plot. To determine fresh and dry mass of the cover plants, the entire above-the-ground (or aerial) part of the plants was collected randomly at the beginning of the flowering period in a $0.5 \mathrm{~m}^{2}$ area $(1.0 \mathrm{~m} \times 0.5 \mathrm{~m})$. The material was weighed and put into a forced-air circulation oven at $65{ }^{\circ} \mathrm{C}$ to constant weight to determine the dry mass of the aerial part of the plant (DMAP). The results were extrapolated to one hectare and expressed in $\mathrm{Mg}$ $\mathrm{ha}^{-1}$.

Two samplings were conducted in the experimental area, the first in 2011 (Table 1) and the second in 2012, when the cover plants were in full blossom. Two samples of each layer were collected for determination of soil bulk density $\left(\rho_{\mathrm{b}}\right)$, soil moisture (Ms), soil penetration resistance (SPR) and soil porosity (macro, micro and total). Samples with preserved structure were collected with metal cylinders measuring $4.0 \mathrm{~cm}$ high, $4.05 \mathrm{~cm}$ diameter and with a volume of $64.8 \mathrm{~cm}^{3}$ from the following layers: $0.0-0.05 \mathrm{~m}, 0.05-0.10 \mathrm{~m}$ and $0.10-0.20 \mathrm{~m}$. Afterwards, the samples were saturated gradually to reach approximately $2 / 3$ of the ring height. After saturation, the samples were subjected to $-6 \mathrm{kPa}$ pressure for determination of micro, macro and total porosity using the tension table method (EMBRAPA, 1997).

Table 1. Physical characteristics of the experimental area in Humaitá/AM in 2011, in $0.0-0.20$ m layer, before cultivation with cover plans

\begin{tabular}{|c|c|c|c|c|c|c|}
\hline Treatment $^{(1)}$ & $\rho_{\mathrm{b}}$ & SPR & $\mathrm{Mv}$ & $\mathrm{Pt}$ & Macro & Micro \\
\hline & -- $\mathrm{Mg} \mathrm{m}^{-3}$-- & ---- MPa ---- & - & - & $n^{-3}---$ & 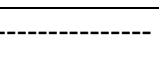 \\
\hline \multicolumn{7}{|l|}{ Brachiaria } \\
\hline $\mathrm{CM}$ & 1.29 & 0.88 & 0.34 & 0.53 & 0.12 & 0.42 \\
\hline $\mathrm{CMc} 4$ & 1.41 & 1.87 & 0.30 & 0.50 & 0.09 & 0.42 \\
\hline $\mathrm{CMc} 8$ & 1.49 & 1.68 & 0.31 & 0.50 & 0.07 & 0.43 \\
\hline \multicolumn{7}{|l|}{ Crotalaria } \\
\hline $\mathrm{CM}$ & 1.40 & 0.84 & 0.29 & 0.49 & 0.09 & 0.40 \\
\hline $\mathrm{CMc} 4$ & 1.43 & 1.60 & 0.30 & 0.49 & 0.08 & 0.42 \\
\hline $\mathrm{CMc} 8$ & 1.44 & 1.73 & 0.30 & 0.51 & 0.08 & 0.42 \\
\hline \multicolumn{7}{|l|}{ Stylosanthes } \\
\hline $\mathrm{CM}$ & 1.34 & 0.92 & 0.32 & 0.52 & 0.10 & 0.42 \\
\hline $\mathrm{CMc} 4$ & 1.44 & 1.52 & 0.29 & 0.50 & 0.08 & 0.41 \\
\hline $\mathrm{CMc} 8$ & 1.43 & 1.71 & 0.31 & 0.51 & 0.08 & 0.43 \\
\hline
\end{tabular}

Note. ${ }^{(1)} \rho_{\mathrm{b}}$ : bulk density; SPR: soil penetration resistance; Mv: volumetric moisture; Pt: total soil porosity; Macro: macroporosity; Micro: microporosity; CM: conventional soil management (tillage) without additional compaction; $\mathrm{CMc} 4$ and $\mathrm{CMc} 8$ : conventional soil management with additional compaction by $6 \mathrm{Mg}$ tractor traffic in four and eight passes, respectively. 
When the samples attained balance in the referred pressure, soil penetration resistance was measured, using an electronic penetrometer with constant speed of $1 \mathrm{~cm} \mathrm{~min}^{-1}$, base diameter of $4 \mathrm{~mm}$ and semi-angle of $30^{\circ}$, developed by Serafim et al. (2008). The penetration rod was introduced into the geometric center of each sample. The results in the 5-mm higher and lower part of the samples were disregarded, aiming to eliminate the sample peripheral effect. The frequency of readings of the SPR corresponded to the values obtained every 0.25 seconds, resulting in a total of 800 readings per sample, and a mean value of the readings was used. After the SPR determination the samples were put in oven at $105-110^{\circ} \mathrm{C}$ for $48 \mathrm{~h}$, and the soil volumetric moisture and density were obtained using the volumetric ring method.

Data were subjected to analysis of variance and, when significant, to the Tukey's test at $5 \%$ probability level to compare the means. After standardization of the variables with zero mean and unit variance $(\mu=0, \sigma=1)$, data were subjected to Principal Component Analysis (PCA). The criterion for choosing the number of components was by selecting those that had eigenvalues above 1.00, as proposed by Kaiser (1958), and were able to synthetize an accumulated variance above 70\% (Hair, Black, Babin, Anderson, \& Tatham, 2009). This analysis was carried out using the Statistica 7.0 software program.

\section{Results and Discussion}

Soil compaction caused by tractor increased the soil bulk density and penetration resistance, resulting in reduced soil moisture (Ms), reduced macroporosity and total porosity (Pt) (Figures 2 and 3). Soil moisture was the only property that did not exhibit difference in the averages between tractor passes, layers and cover plants (Figure $2 b)$. On the other hand, $\rho_{\mathrm{b}}$ and SPR exhibited a more varied behavior, differing statistically according to the number of passes, depths and cover plants. Emphasis is given to the $0.10-0.20 \mathrm{~m}$ layer, where tillage did not have a significant influence on the physical attributes assessed.

In general, the 0.0-0.05 m layer exhibited lower $\rho_{b}$ values compared to the $0.05-0.10 \mathrm{~m}$ and $0.10-0.20 \mathrm{~m}$ layers (Figure 2a). This was also pointed out in the study of Andrade, Stone, and Silveira (2009) in determining the effect of cover crops (crotalaria and stylosanthes) on the physical quality of a Dystrophic Red Latosol under no-tillage. The cover crops, due to each plant's growth habit, played a different role in reducing $\rho_{\mathrm{b}}$, and brachiaria and crotalaria were the cover plants that indicated the lowest vales of $\rho_{b}\left(1.15\right.$ and $1.16 \mathrm{Mg} \mathrm{m}{ }^{-3}$, respectively, in the 0.0-0.05 m layer, without additional compaction. On the other hand, the exploratory aggressiveness and uniformity of the stylosanthes' dense fasciculate root system minimized the negative impact of compaction with $\mathrm{CMc} 4$ and $\mathrm{CMc}$. The stylosanthes' mechanical behavior that was found in this study validates its contribution as a soil biological decomposer (Negreiros Neto, A. Santos, P. Santos, T. Santos, \& Faria, 2010; Castagnara, T. Zoz, Castro, A. Zoz, \& Oliveira, 2013). 


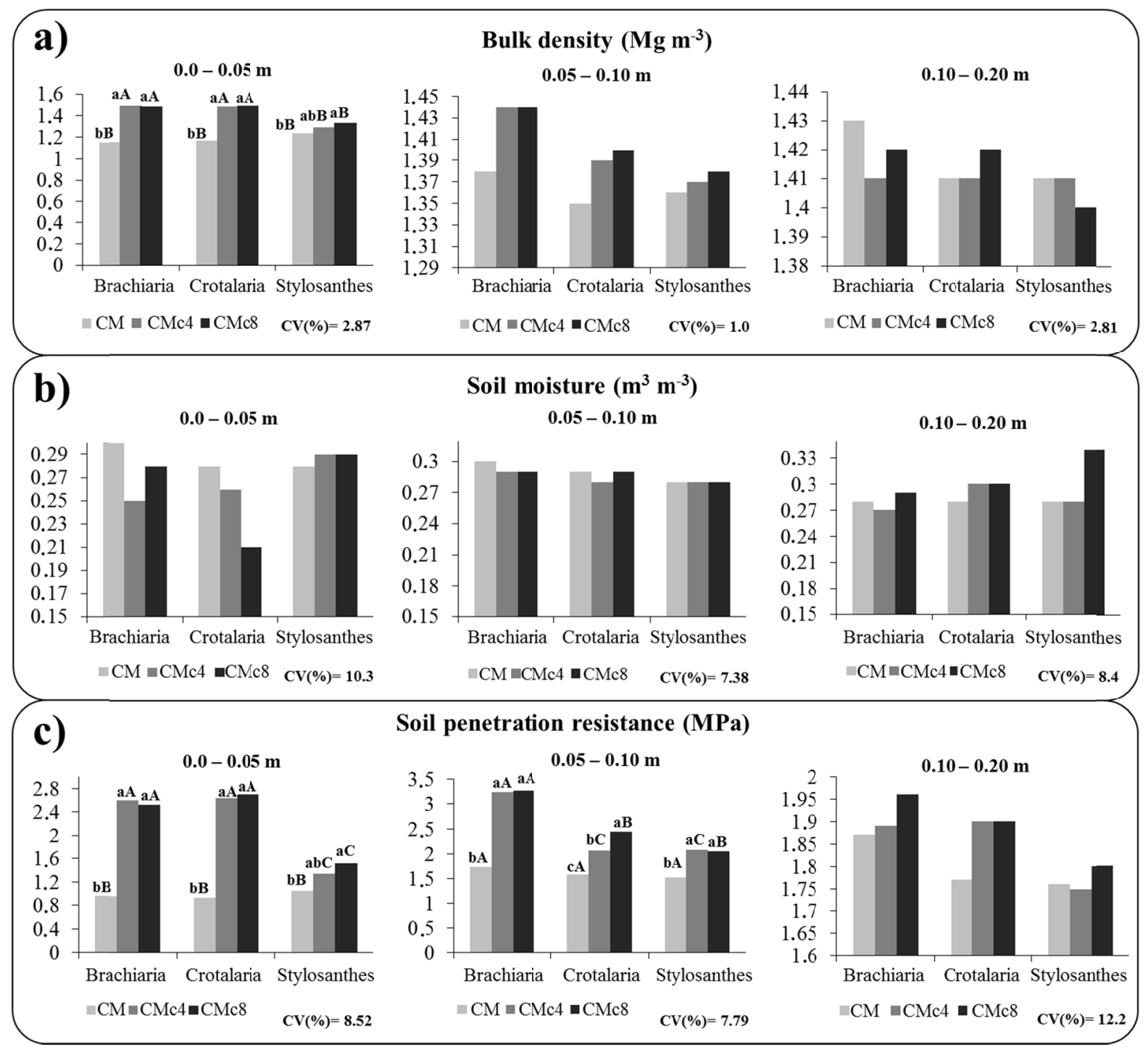

Figure 2. Physical properties of the soil [Bulk density (a); Soil moisture (b); Soil penetration resistance (c)], in different layers and compaction states after flowering of three cover plants

Note. CM: conventional soil management without additional compaction; $\mathrm{CMc} 4$ and $\mathrm{CMc} 8$ : conventional soil management with additional compaction using a $6 \mathrm{Mg}$ tractor in four and eight passes, respectively. Means followed by same uppercase letters between cover plants and low case letters between compaction states do not differ statistically from each other by the Tukey's test at 5\% probability. CV: coefficient of variation.

The stylosanthes' beneficial effect in promoting lower $\rho_{\mathrm{b}}$ values, compared to the other cover plants and all layers assessed, corroborate the investigations of Negreiros Neto et al. (2010) (Figure 2a). These authors found that the stylosanthes contribution to soil decompression, and consequently, on reduced $\rho_{\mathrm{b}}$, is due to its vigorous growth habit and deep root system, which can reach up to $1.5 \mathrm{~m}$ (Castagnara et al., 2013). The $\rho_{\mathrm{b}}$ values in the $\mathrm{CMc} 4$ and $\mathrm{CMc} 8$ systems corroborate the results reported by Bergamin et al. (2010), in which the authors did not find a significant difference in layers $0.10-0.15 \mathrm{~m}$ and $0.15-0.20 \mathrm{~m}$ in soil under wheeling pressure of two, four and six tractor passes.

The SPR varied from 0.94 to $3.26 \mathrm{MPa}$ and increased as the soil density increased, which is in agreement with Reinert, Albuquerque, Reichert, Aita, and Andrada (2008) when they assessed the physical quality of a Red Argisol cultivated under no-tillage after cultivation of cover plants. The SPR values found in layers $0.0-0.05 \mathrm{~m}$ and $0.05-0.10 \mathrm{~m}$ increased significantly under the pressure of tractor passage in treatments under $\mathrm{CMc} 4$ and $\mathrm{CMc} 8$, exhibiting values higher than $3 \mathrm{MPa}$ in the $0.05-0.10 \mathrm{~m}$ layer and, exclusively, in the soil cultivated with 
brachiaria (Figure 2c). So, the values slightly higher than $2 \mathrm{MPa}$ for crotalaria and stylosanthes and higher than 3 $\mathrm{MPa}$ for brachiaria indicate limiting conditions to the root growth (Couto et al., 2013; Deperon Júnior, Nagahama, Olszevski, Cortez, \& Souza, 2016).

In the 0.10-0.20 m layer, irrespective of the kind of cover plant, the treatments (CM, CMc4 and CMc8) did not differ from each other and exhibited lower SPR values (1.75 and $1.96 \mathrm{MPa}$ ) (Figure 2c). In the study conducted by Tavares Filho, Barbosa, Guimarães, and Fonseca (2001), they found SPR values higher than the critical limit but without limitation to the root development. On the other hand, Andrade, Stone, and Godoy (2013) considered that SPR values $\geq 1.9 \mathrm{MPa}$ were indicative of compacted soils, limiting plant growth. These conflicts allow to state that any inference about the soil physical quality requires multiple information on the main properties that are sensitive to soil management, e.g. a porous soil area, to avoid wrong conclusions and inadequate soil management.

As no significant differences were found in the $\rho_{\mathrm{b}}$, Ms and SPR properties in the $0.10-0.20 \mathrm{~m}$ layer, the same was observed for the Pt, Macro and Micro (Figure 3). Macro and Pt and were slightly affected in the 0.0-0.05 $\mathrm{m}$ and 0.10-0.20 $\mathrm{m}$ layers in the CM treatment, a behavior that was in agreement with that found by Bergamin et al. (2010), which can be explained in the investigation conducted by Camargo and Alleoni (2006). According to these authors, tractor wheeling at a pressure of up to $110 \mathrm{kPa}$ is not enough to change $\mathrm{Pt}$ and macro porosity on the soil surface, considering that the wheeling pressure on the soil surface is nearly the same as the internal tires pressure. Kondo and Dias Júnior (1999) found that the $183 \mathrm{kPa}$ pressure did not compress a very clayed Red Latosol, because pressures in this range did not exceed the bearing capacity of soil.

Compaction exerted by the tractor wheeling in the CMc4 and CMc8 treatments caused a total reduction of the pores volume in the $0.0-0.05 \mathrm{~m}$ and $0.05-0.10 \mathrm{~m}$ layers, reflecting immediately in the reduction of Macro (Figures $3 \mathrm{a}$ and $3 \mathrm{~b}$ ). It can be seen that there was no statistical difference for Macro in the soils with four and eight passes, which indicates that the soil has already attained a maximum macropores reduction. However, the difference only occurred in the cover crops, showing that stylosanthes, brachiaria and crotalaria present specific biological characteristics in the soil physical quality (Andrade et al., 2009). In quantitative terms, except for the $\mathrm{CM}$ treatment in the 0.0-0.05 m layer and irrespective of the cover plants, the compaction-induced Macro values are quite below the value that is considered critical, i.e., the minimum aeration value of $0.10 \mathrm{~m}^{3} \mathrm{~m}^{-3}$ that is necessary for root development, as pointed out by Gupta and Allmaras (1987).

It was found that in the $\mathrm{CMc} 8$, the low Macro values tended to remain the same in the $0.05-0.10 \mathrm{~m}$ and $0.10-0.20$ $\mathrm{m}$ layers, where they did not differ significantly (Figure 3b). This behavior, coinciding with the highest $\rho_{\mathrm{b}}$ and SPR values indicate that the pressure exerted in the CMc8 or over resulted in a new rearrangement of the soil particles, reaching maximum soil compaction. The results lead us to interpret that, under such mechanical conditions imposed by traffic, cover crops have difficulty to develop and lose their biological soil scarification potential (Andrade Neto, Miranda, Duda, Góes, \& Lima, 2010; Villa Secco, Tokura, \& Pilatti, 2017). 


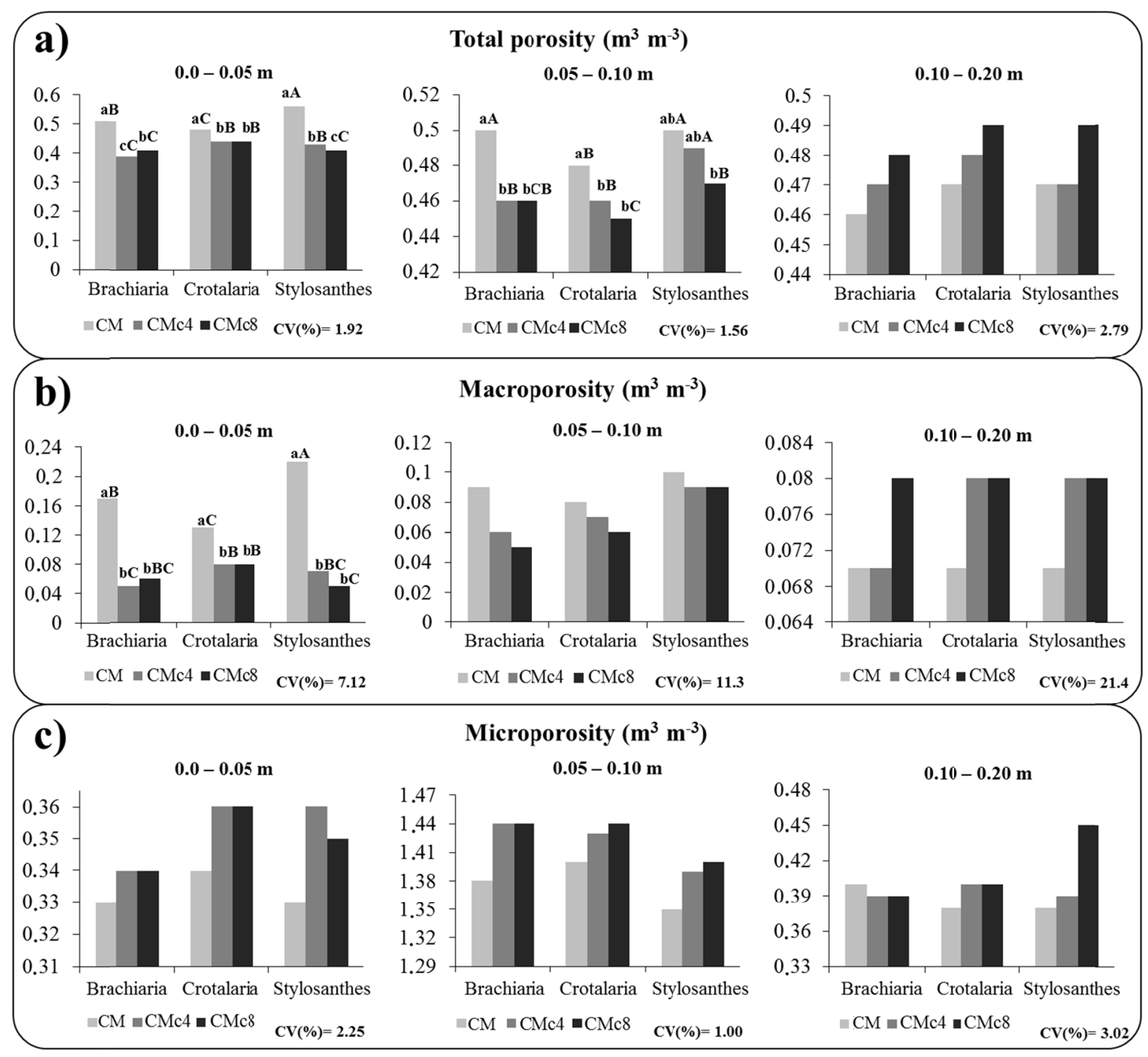

Figure 3. Physical properties of the soil [Total porosity (a); Macroporosity (b); Microporosity (c)] in different layers and compaction states after flowering of three cover plants

Note. CM: conventional soil management without additional compaction; $\mathrm{CMc} 4$ and $\mathrm{CMc} 8$ : conventional soil management with additional compaction with traffic of a $6 \mathrm{Mg}$ tractor in four and eight passes, respectively. Means followed by same capital letters between cover plants and small letters between compaction states do not differ statistically from each other by the Tukey's test at 5\% probability. CV: coefficient of variation.

In the different treatments $(\mathrm{CM}, \mathrm{CMc} 4, \mathrm{CMc} 8$ and plant covers) and layers, Micro did not exhibit a significant influence of the pressure exerted by tractor wheeling, even with alterations of the Pt and Macro in the surface layer (Figure 3c). The same occurred in the study by Valadão et al. (2015), where traffic on a dystrophic yellow Red Latosol increased the SPR and $\rho_{\mathrm{b}}$, respectively, reduced Macro and did not affect Micro. The authors explained that this is due to the fact that the smaller size pores are resistant to the changes imposed by pressures applied above the bearing capacity of soil.

In general, improvement or resilience of the soil physical properties to compaction strengths imposed by the traffic passages, occurred in the soil under cover plants, in the following ascending order: brachiaria $<$ crotalaria $<$ stylosanthes. However, the improved physical quality of the soil caused by the stylosanthes requires careful consideration, since it depends largely on the soil texture. Negreiros Neto et al. (2010), when they assessed the stylosanthes potential to compression strengths in an Entisol Quartzipsamment (9\% clay and $87 \%$ sand) and a eutroferric Dark Red Argisol (31\% clay and 61\% sand), concluded that Stylosanthes cv. Campo Grande 
contributed to reduce compaction of sandy soil, as is the case of Entisol, which is an expected behavior, since the species is native to the Cerrado (savanna), predominant in sandy and well-drained soils (Andrade, Assis, \& Sales, 2010).

Soil compaction had an influence on the parameters of the cover plants assessed (Table 2). According to Modolo, Trogello, Nunes, and Modernel (2011), this happens because compaction reduces water infiltration, temperature and soil aeration and, consequently, the plant emergence and growth. Emergence suffered a reduction of 16, 12 and $11 \%$ for brachiaria, crotalaria and stylosanthes, respectively, in the CMc4 compared to CM. With the CMc8, such decrease reached $23 \%, 39 \%$ and $12 \%$ for brachiaria, crotalaria and stylosanthes, respectively. In turn, emergence of the cover plants did not differ significantly from each other. Considering a higher emergence rate, $85 \%$ on average, for the stylosanthes, $82 \%$ for crotalaria, and $80 \%$ for brachiaria, it confirms the preferable growth habit in more sandy soils (Andrade et al., 2010; Castagnara et al., 2013), as is the case of the plyntic Haplic-Alitic Cambisol of the present study, classified as a loam-clay-silt soil.

Table 2. Plants emergence, height, fresh mass of aerial part (FMAP) and dry mass of aerial part (DMAP) of three cover crops grown in different stages of soil compaction

\begin{tabular}{|c|c|c|c|}
\hline Treatment $^{(1)}$ & Brachiaria & Crotalaria & Stylosanthes \\
\hline \multicolumn{4}{|c|}{ Plants emergence (\%) } \\
\hline $\mathrm{CM}$ & $92.6 \mathrm{aA}$ & $98.6 \mathrm{aA}$ & $92.0 \mathrm{aA}$ \\
\hline $\mathrm{CMc} 4$ & $78.3 \mathrm{bA}$ & $87.3 \mathrm{bA}$ & $82.0 \mathrm{bA}$ \\
\hline CMc8 & $71.6 \mathrm{bA}$ & $60.3 \mathrm{cB}$ & $81.0 \mathrm{bA}$ \\
\hline CV\% & & 5.61 & \\
\hline \multicolumn{4}{|l|}{ Height $(\mathrm{cm})$} \\
\hline $\mathrm{CM}$ & $85 \mathrm{aA}$ & $80 \mathrm{aA}$ & $43 \mathrm{aB}$ \\
\hline CMc4 & $75 \mathrm{aA}$ & $65 \mathrm{bA}$ & $36 \mathrm{aB}$ \\
\hline CMc8 & $60 \mathrm{bA}$ & $61 \mathrm{bA}$ & $35 \mathrm{aB}$ \\
\hline $\mathrm{CV} \%$ & & 8.00 & \\
\hline \multicolumn{4}{|c|}{$F M A P\left(M g h a^{-1}\right)$} \\
\hline $\mathrm{CM}$ & $11.41 \mathrm{aA}$ & $5.06 \mathrm{aB}$ & $13.00 \mathrm{aA}$ \\
\hline $\mathrm{CMc} 4$ & $9.09 \mathrm{bB}$ & $4.50 \mathrm{aC}$ & $12.43 \mathrm{aA}$ \\
\hline CMc8 & $6.58 \mathrm{cB}$ & $3.81 \mathrm{aC}$ & $10.52 \mathrm{bA}$ \\
\hline CV\% & & 10.40 & \\
\hline \multicolumn{4}{|c|}{$D M A P\left(M g h a^{-1}\right)$} \\
\hline $\mathrm{PC}$ & $3.17 \mathrm{aB}$ & $1.70 \mathrm{aC}$ & $4.04 \mathrm{aA}$ \\
\hline $\mathrm{PCc} 4$ & $3.04 \mathrm{aA}$ & $1.54 \mathrm{aB}$ & $3.21 \mathrm{bA}$ \\
\hline $\mathrm{PCc} 8$ & $2.25 \mathrm{bB}$ & $1.41 \mathrm{aC}$ & $2.77 \mathrm{cA}$ \\
\hline CV\% & & 5.85 & \\
\hline
\end{tabular}

(1) $\mathrm{CM}$ : conventional soil management (tillage) without additional compaction; $\mathrm{CMc} 4$ and $\mathrm{CMc} 8$ : conventional soil management with additional compaction by traffic of $6 \mathrm{Mg}$ tractor in four and eight passes, respectively. Means followed by same letter did not differ statistically from each other, uppercase in column and low case in row, by the Tukey's test at $5 \%$ probability level. CV: coefficient of variation.

Studies by Modolo, Fernandes, Schaefer, and Silveira (2008) found lower emergence rates in soybean cultivated under wheel loads ranging from 0 to $50 \mathrm{~N}$, making the contact between soil and seed difficult, as well as water absorption, delaying the germination process. However, the lowest emergence rates observed were under wheel loads of $140 \mathrm{~N}$ due to surface sealing, little oxygen entry, causing the seedling to consume much more energy to emerge.

When analyzing the production of dry matter of the aerial part (DMAP) of the crotalaria in different soil managements (Table 2), it is possible to observe that there was no significant difference and yet it produced a lower amount of DMAP $\left(1.70\right.$ to $\left.1.41 \mathrm{Mg} \mathrm{ha}^{-1}\right)$ than the other cover crops assessed. In the plots cultivated with brachiaria under average $\rho_{\mathrm{b}}$ of $1.4 \mathrm{Mg} \mathrm{m}^{-3}$, there was a significant reduction only in the $\mathrm{CMc} 8$ treatment compared to the CMc4 and CM. Studies conducted by Medeiros, Soares, and Guimarães (2005) explain that a decreased DMAP is due to changes in the soil physical-hydro properties caused by soil compression, reducing 
the nutrients uptake and accumulation of carbon by photosynthesis which, sequentially, diminishes the development of the root system and the aerial part of plants.

The stylosanthes crop exhibited a statistical difference, regarding the type of soil management, in the amount of DMAP, producing a greater amount of dry matter/hectare even with increased compression. Castagnara et al. (2013) reported that, under protected cultivation, the DMAP of stylosanthes cv. Campo Grande with $\rho_{\mathrm{b}}$ below $1.60 \mathrm{Mg} \mathrm{m}^{-3}$ did not exhibit a significant difference, even with an increased amount produced. Thus, the results demonstrate the potential use of cover plants as an important natural bioindicator of the soil physical quality (Freddi et al., 2007; Andrade et al., 2010; Villa et al., 2017).

Principal components analysis (PCA) allowed to distinguish better which plant was more resistant to soil compression (Figure 4). The variance retained in the two first principal components was $94.95 \%(94.57 \%$ in the $\mathrm{PC} 1$ and $4.70 \%$ in $\mathrm{PC} 2$ ). $\mathrm{PC} 1$ characterized a process involving the plant height according to the soil compaction levels. PC2 included the emergence, FMAP and DMAP parameters that were more associated with soil compaction.

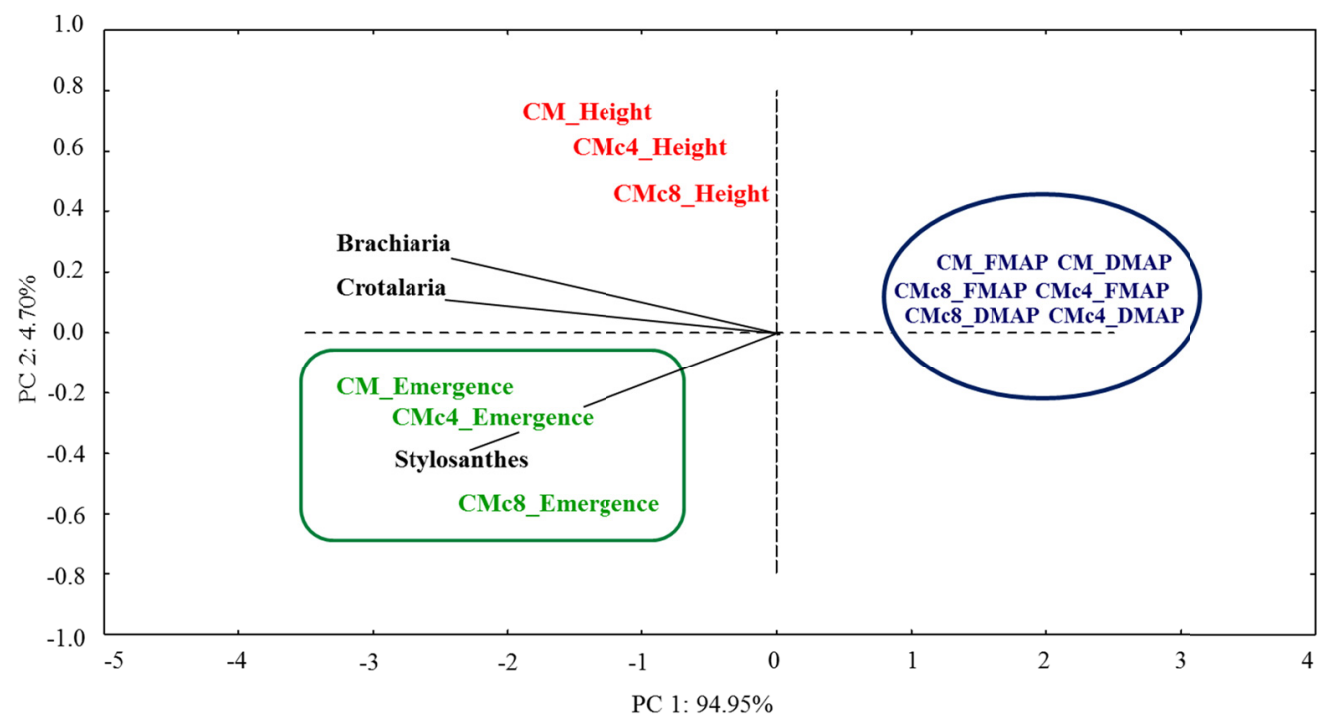

Figure 4. Principal components analysis of the parameters (plant height, emergence, fresh mass of aerial part (FMAP) and dry mass of aerial part (DMAP)) of cover plants (brachiaria, crotalaria and stylosanthes), indicators of higher plant resistance to soil compaction

It can be seen that each cover plant reacted differently to soil compression, a feature attributed to its biological aspects and growth habit. It can be seen that stylosanthes have more potential of emergence than the other plants in tillage systems with or without additional compaction, while brachiaria and crotalaria reach higher heights when they succeed to emerge. On the other hand, the FMAP and DMAP, occurring alone in quadrant one, indicate that, when assessed alone, they are not good indicators of soil compaction. In summary, the information obtained from the univariate and multivariate analysis show that stylosanthes have more efficiency or resilience to soil compression. This characteristic is due to the emergence potential and greater amount of DMAP and FMAP deposited on the soil, which softens the adverse effects of heavy traffic.

\section{Conclusions}

Conventional soil management with additional compaction does not affect significantly the soil physical properties at a depth of $0.10-0.20 \mathrm{~m}$, and only the soil moisture does not differ with soil management, irrespective of the depth and the kind of cover plant.

Traffic wheeling in four passes resulted in increased soil density and macroporosity in the 0.0-0.05 m layer, and in soil resistance to penetration and total porosity in the layer up to $0.10 \mathrm{~m}$. 
Cover crops are important in maintaining soil physical quality to reduce the negative effects of compacting forces, especially to stylosanthes cv. Campo Grande that provided greater soil protection in systems with or without addition of compaction, conditioning the lowest values of bulk density and soil resistance to penetration.

\section{References}

Andrade Neto, R. C., Miranda, N. O., Duda, G. P., Góes, G. B., \& Lima, A. S. (2010) Crescimento e produtividade do sorgo forrageiro BR 601 sob adubação verde. Revista Brasileira de Engenharia Agrícola e Ambiental, 14(2), 124-130. https://doi.org/10.1590/S1415-43662010000200002

Andrade, C. M. S., Assis, G. M. L., \& Sales, M. F. L. (2010). Estilosantes Campo Grande: Leguminosa forrageira recomendada para solos arenosos do Acre (Circular Técnica, 55, p. 12). Rio Branco: Embrapa Acre.

Andrade, R. S., Stone, L. F., \& Godoy, S. G. (2013). Estimativa da resistência do solo à penetração baseada no índice S e no estresse efetivo. Revista Brasileira de Engenharia Agrícola e Ambiental, 17(9), 932-937. https://doi.org/10.1590/S1415-43662013000900004

Andrade, R. S., Stone, L. F., \& Silveira, P. M. (2009). Culturas de cobertura e qualidade física de um Latossolo em plantio direto. Revista Brasileira de Engenharia Agrícola e Ambiental, 13(4), 411-418. https://doi.org/ 10.1590/S1415-43662009000400007

Bergamin, A. C., Vitorino, A. C. T., Franchini, J. C., Souza, C. M. A., \& Souza, F. R. (2010). Compactação em um Latossolo Vermelho distroférrico e suas relações com o crescimento radicular do milho. Revista Brasileira de Ciência do Solo, 34(3), 681-691. https://doi.org/10.1590/S0100-06832010000300009

Camargo, O. A., \& Alleoni, L. R. F. (2006). Causas da compactação do solo. Retrieved December 11, 2017, from http://www.infobibos.com/Artigos/CompSolo/C3/Comp3.htm

Campos, M. C. C. (2009). Pedogeomorfologia aplicada à ambientes amazônicos do médio Rio Madeira (PE) (Master's Thesis, Universidade Federal Rural de Pernambuco, Recife, Brazil).

Castagnara, D. D., Zoz, T., Castro, A. M. C., Zoz, A., \& Oliveira, P. S. R. (2013). Crescimento de Stylosanthes cv. Campo Grande em diferentes níveis de densidade de um Latossolo Vermelho. Revista Ciência Agronômica, 44(2), 260-266. https://doi.org/10.1590/S1806-66902013000200007

Castro, O. M., Vieira, S. R., Siqueira, G. M., \& Andrade, C. A. (2009). Atributos físicos e químicos de um Latossolo Vermelho eutroférrico sob diferentes sistemas de preparo. Bragantia, 68(4), 1047-1057. https://doi.org/10.1590/S0006-87052009000400026

Couto, R. F., Reis, E. F., Viana, P. M. F., Holtz, V., Oliveira, L. A., \& Alves, S. M. F. (2013). Compactação e recalque superficial de um Latossolo Vermelho em condição de campo e laboratório. Revista Brasileira de Engenharia Agrícola e Ambiental, 17(11), 1239-1245. https://doi.org/10.1590/S1415-43662013001100016

Deperon Júnior, M. A., Nagahama, H. J., Olszevski, N., Cortez, J. W., \& Souza, E. B. (2016). Influência de implementos de preparo e de níveis de compactação sobre atributos físicos do solo e aspectos agronômicos da cultura do milho. Revista Engenharia Agrícola, 36(2), 367-376. https://doi.org/10.1590/1809-4430-Eng. Agric.v36n2p367-376/2016

EMBRAPA (Empresa Brasileira de Pesquisa Agropecuária). (1997). Manual de métodos de análise de solo (p. 212). Rio de Janeiro: Embrapa Solos.

EMBRAPA (Empresa Brasileira de Pesquisa Agropecuária). (2011). Manual de métodos de análise de solo (2nd ed., p. 230). Rio de Janeiro: Embrapa Solos.

Freddi, O. S., Centurion, J. F., Beutler, A. N., Aratani, R. G., \& Leonel, C. L. (2007). Compactação do solo no crescimento radicular e produtividade da cultura do milho. Revista Brasileira de Ciência do Solo, 31(4), 627-636. https://doi.org/10.1590/S0100-06832007000400003

Gomes, R. P., Campos, M. C. C., Soares, M. D. R., Silva, D. M. P., Cunha, J. M., Franciscon, U., ... Brito, W. B. M. (2017). Spatial variability of aggregates and organic carbon under three different uses of indian black earth in southern Amazonas. Bioscience Journal, 33(6), 1513-1522. https://doi.org/10.14393/BJ-v33n6a 2017-37142

Gupta, S. C., \& Allmaras, R. R. (1987). Models to assess the susceptibility of soils to excessive compaction. Advances in Soil Science, 6, 65-100. https://doi.org/10.1007/978-1-4612-4682-4_2 
Hair, F. J., Black, W. C., Babin, B. J., Anderson, R. E., \& Tatham, R. L. (2009). Análise multivariada de dados. (6th ed., p. 688). São Paulo: Bookman.

Kaiser, H. F. (1958). The varimax criterion for analytic rotation in factor analysis. Psychometrika, 23(3), 187-200. https://doi.org/10.1007/BF02289233

Kondo, M. K., \& Dias Júnior, M. S. (1999). Estimativa do efeito do uso e da umidade do solo sobre a compactação adicional de três Latossolos. Revista Brasileira de Ciência do Solo, 23(4), 211-218. https://doi.org/10.1590/S0100-06831999000200004

Marsili, A., Servadio, P., Pagliai, M., \& Vignozzi, N. (1998) Changes of some physical properties of a clay soil following passage of rubber- and metal-tracked tractors. Soil and Tillage Research, 49(3), 185-199. https://doi.org/10.1016/S0167-1987(98)00169-X

Martinkoski, L., Vogel, G. F., Jadoski, S. O., \& Watzlawick, L. F. (2017). Qualidade física do solo sob manejo silvipastoril e floresta secundária. Floresta e Ambiente, 24(e20160282), 1-9. https://doi.org/10.1590/ 2179-8087.028216

Medeiros, R. D., Soares, A. A., \& Guimarães, R. M. (2205). Compactação do solo e manejo de água I: efeitos sobre a absorção de N, P, K, massa seca de raízes e parte aérea de plantas de arroz. Ciência Agrotécnica, 29(5), 940-947. https://doi.org/10.1590/S1413-70542005000500004

Modolo, A. J., Fernandes, A. C., Schaefer, C. E. G., \& Silveira, J. C. M. (2008). Efeito da compactação do solo sobre a emergência de plântulas de soja em sistema plantio direto. Ciência e Agrotecnologia, 32(4), 1259-1265. https://doi.org/10.1590/S1413-70542008000400034

Modolo, A. J., Trogello, E., Nunes, A. L., \& Modernel, J. C. (2011). Efeito da compactação do solo sobre a semente no desenvolvimento da cultura do feijão. Acta Scientiarum Agronomy, 33(1), 89-95. https://doi.org/10.4025/actasciagron.v33i1.4236

Negreiros Neto, J. V., Santos, A. C., Santos, P. M., Santos, T. M., \& Faria, A. F. G. (2010). Atributos físicos de solos sob a consorciação gramíneas-leguminosas no norte do estado do Tocantins. Engenharia na Agricultura, 18(2), 140-150. https://doi.org/10.13083/1414-3984.v18n02a05

Reinert, D. J., Albuquerque, J. A., Reichert, J. M., Aita, C., \& Andrada, M. M. C. (2008). Limites críticos de densidade do solo para o crescimento de raízes de plantas de cobertura em Argissolo Vermelho. Revista Brasileira de Ciência do Solo, 32(5), 1805-1816. https://doi.org/10.1590/S0100-06832008000500002

Rosa, D. M., \& Lima, G. P. (2017). Substâncias húmicas do solo cultivado com plantas de cobertura em rotação com milho e soja. Revista Ciência Agronômica, 48(2), 221-230.

Salton, J. C., Mielniczuk, J., Bayer, C., Boeni, M., Conceição, P. C., Fabrício, A. C., ... Broch, D. (2008). Agregação e estabilidade de agregados do solo em sistemas agropecuários em Mato Grosso do Sul. Revista Brasileira de Ciência do Solo, 32(1), 11-21. https://doi.org/10.1590/S0100-06832008000100002

Serafim, M. E., Vitorino, A. C. T., Souza, C. M. A., Prado, E. D., Venturin, J. C., \& Yamamoto, N. T. (2008). Desenvolvimento de um penetrógrafo eletromecânico de bancada. Revista Ciências Técnicas Agropecuárias, $17(1), 61-65$.

Servadio, P., Marsili, A., Vignozzi, N., Pellegrini, S., \& Pagliai, M. (2005). Effects on some soil qualities in central Italy following the passage of four wheel drive tractor fitted with single and dual tires. Soil and Tillage Research, 84(1), 87-100. https://doi.org/10.1016/j.still.2004.09.018

Souza Neto, E. L., Andrioli, I., Beutler, A. N., \& Centurion, J. F. (2008). Atributos físicos do solo e produtividade de milho em resposta a culturas de pré-safra. Pesquisa Agropecuária Brasileira, 43(2), 255-260. https://doi.org/10.1590/S0100-204X2008000200015

Souza, G. S., Souza, Z. M., Silva, R. B., Barbosa, R. S., \& Araújo, F. S. (2014). Effects of traffic control on the soil physical quality and the cultivation of sugarcane. Revista Brasileira de Ciência do Solo, 38(1), $135-146$ https://doi.org/10.1590/S0100-06832014000100013

Tavares Filho, J., Barbosa, G. M. C., Guimarães, M. F., \& Fonseca, I. C. B. (2001). Resistência à penetração e desenvolvimento do sistema radicular do milho (Zea mays) sob diferentes sistemas de manejo em um Latossolo Roxo. Revista Brasileira de Ciência do Solo, 25(3), 725-730. https://doi.org/10.1590/S010006832001000300022 
Teodoro, R. B., Oliveira, F. L., Silva, D. M. N., Fávero, C., \& Quaresma, M. A. L. (2011). Leguminosas herbáceas perenes para utilização como coberturas permanentes de solo na Caatinga Mineira. Revista Ciência Agronômica, 42(2), 292-300. https://doi.org/10.1590/S1806-66902011000200006

Valadão, F. C. A., Weber, O. L. S., Valadão Júnior, D. D., Scapinelli, A., Deina, F. R., \& Bianchini, A. (2015). Adubação fosfatada e compactação do solo: sistema radicular da soja e do milho e atributos físicos do solo. Revista Brasileira de Ciência do Solo, 39(1), 245-255. https://doi.org/10.1590/01000683rbcs20150144

Vasconcelos, R. F. B., Souza, E. R., Cantalice, J. R., \& Silva, L. S. (2014). Qualidade física de um Latossolo Amarelo de tabuleiros costeiros em diferentes sistemas de manejo da cana-de-açúcar. Revista Brasileira de Engenharia Agrícola e Ambiental, 18(4), 381-386. https://doi.org/10.1590/S1415-43662014000400004

Villa, B., Secco, D., Tokura, L. K., \& Pilatti, M. A. (2017). Impacto do uso de espécies de cobertura na estrutura de um Latossolo Argiloso e seus reflexos no rendimento de grãos de soja. Acta Iguazu, 6(2), 1-12.

\section{Copyrights}

Copyright for this article is retained by the author(s), with first publication rights granted to the journal.

This is an open-access article distributed under the terms and conditions of the Creative Commons Attribution license (http://creativecommons.org/licenses/by/4.0/). 